\title{
The Problem of Torture Practice in Criminal Investigation in Kazakhstan
}

\author{
Roman Sergeyevich, Bramontov
}

\author{
Kazakh Humanities and Law University
}

Email: bramontovr@rambler.ru

Doi:10.5901/mjss.2014.v5n23p639

\begin{abstract}
The article investigates the problem of systematic application of torture in criminal investigation in Kazakhstan. Modern methods of torture most often used by police officers are described. Special focus is given to the identification of causes fostering torture practice in crime investigation as well as its prevention.
\end{abstract}

Keywords: torture, crime investigation, torture methods, causes of torture practice, torture prevention.

\section{Introduction}

Modern Kazakhstan considers itself the state governed by the rule of law. Its highest values are an individual, his life, rights and freedoms (the Constitution of the Republic of Kazakhstan). Such a position should involve ensuring human rights and freedoms in the various spheres of society including crime investigation. In this context, resistance to torture in the field of crime investigation is an integral part of the legal policy of the Republic of Kazakhstan since torture is incompatible with the concept of the rule of law (R. Görling, 2012).

During the years of independence the legislation of Kazakhstan has undergone many positive changes aimed at countering the use of torture in the investigation of crimes.

Thus, in 1998 Kazakhstan joined the UN Convention against Torture and Other Cruel, Inhuman or Degrading Treatment or Punishment.

In 2002 the legislation of Kazakhstan amended the norm stipulating responsibility for torture in criminal investigation as well as the norm of the inadmissibility of evidence obtained by torture.

In 2005 the International Covenant on Civil and Political Rights was ratified.

In 2008 the Optional Protocol to the Convention against Torture and Other Cruel, Inhuman or Degrading Treatment or Punishment was ratified.

In 2009 the Optional Protocol to the International Covenant on Civil and Political Rights, which allows citizens to apply to the UN Committee on Human Rights with individual complaints was ratified.

In 2013 the national preventive mechanism aimed at preventing torture and other cruel, inhuman or degrading treatment or punishment was launched.

This allows some experts argue that Kazakhstan has adapted its legislation towards torture prevention (Fourth Expert Forum on Criminal Justice for Central Asia, 2012).

Official statistics also do not provide reasons for concern. Thus, in 2013 and 2012 in Kazakhstan under article 1411 of the Criminal Code, providing for liability for torture there were 27 offenses registered. In 2011 none of the above mentioned crimes were registered. In 2010 and 2009 there were 11 crimes registered, and 3 under "Torture" provision respectively (Statistical information on registered crimes under Art. 141-1, 2014). The share of offenses under "Torture" provision did not exceed $0.009 \%$ of the total mass of crimes registered in Kazakhstan during the last 5 years.

In such circumstances the problem of torture practice in the field of crime investigation does not seem to be that relevant for Kazakhstan. Torture certainly constitutes a breach of fundamental human rights and freedoms, however Kazakhstan adopted legislative and institutional measures aimed at discouraging the use of torture during criminal proceedings which allow for an effective fight against this type of crime. The use of torture in crime investigation in Kazakhstan is sporadic and does not represent a serious social threat. Officials of law enforcement agencies of Kazakhstan usually adhere to this statement when answering the questions of human rights defenders and journalists.

Edward Peters notes that the best recent evidence indicates that torture is used, formally or informally, in one country out of every three (E. Peters, 1996). It seems that in Central Asian region the situation is much worse and the problem of torture in the investigation of crimes remains relevant for each Central Asian state including Kazakhstan. 
This way, Human Rights Watch in its 667-page report (World Report, 2014) assesses the situation of human rights in more than 90 countries worldwide. It observes continuing severe violations of human rights, including the field of crime investigation in Kazakhstan.

Amnesty International reports of 2011, 2012 and 2013 abound in information on torture and other ill-treatment during criminal investigations in Kazakhstan (Annual Reports, 2011; 2012; 2013).

According to the report presented on the official website Action by Christians for the abolition of torture (ACAT) security forces-inflicted ill-treatment and torture remains a persistent problem in Kazakhstan (Report, 2011).

Considerable divergence between official statistics and estimates of international organizations on the issue of torture in the investigation of crimes in Kazakhstan underscores the importance of studying this problem. In this regard, the independent study was conducted aimed at determining the actual state of the use of torture as well as identifying the reasons for their application in the field of crime investigation in Kazakhstan.

The summarized study results will be described in this article.

\section{Research Methods}

Methodological basis of this study formed: the dialectical method of knowledge of socio-legal phenomena, as well as systematic structural, comparative legal, logical-theoretical and private scientific methods of study. In addition, the research used such sociological techniques as surveys of law enforcement officials and the analysis of specific criminal cases. To achieve objectivity of the research results, these methods have been applied comprehensively.

To determine the actual status of the use of torture in the field of crime investigation, a research was conducted that included the questionnaire and interview of more than 500 people living in the Karaganda Region of Kazakhstan. Among respondents there were 324 students of higher and secondary educational institutions of Kazakhstan aged between 16 and 32, 79 persons convicted of crimes, 68 police officers and prosecutors, 35 lawyers and legal professionals. For objective reasons the study referred to the application of torture in ordinary investigation under the police jurisdiction.

\section{Results and Discussion}

The study showed that every third person suspected of committing a crime was caused physical or mental suffering when delivered to the police department. Also there was physical or mental suffering inflicted on every fifth person delivered to the police department either as a witness of a crime or as having any information about a crime at one's disposal.

According to information received most physical and mental suffering inflicted on persons of lower social strata: the unemployed without permanent place of residence, previously convicted and men aged between 16 and 24 . Respondents also noted that most physical and mental suffering was used in the early hours of the delivery to the police department and, as a rule, by employees responsible for investigating crimes.

These data confirm the systematic use of torture in crimes investigation in Kazakhstan and show considerable discrepancy with not only official statistics, but also the statistics of international and national human rights organizations. In our opinion this is due to the fact that the reports of international human rights organizations and those of Kazakhstan reflect only the most high-profile cases that have received wide publicity and related to completely inhuman behavior while investigating crimes as well as causing serious injury to the victim. However as a rule in the everyday practice the torture is not applied that recklessly. Kazakhstan's policy towards the abolition of torture and the activity of international and national human rights organizations affected the methods of torture used in the investigation of crimes.

The reports of international organizations describe torture accompanied with severe beatings, mutilation, sexual violence after which the victims are in need of medical care, whereas in daily practice other methods are used to enable staff to escape liability.

In particular, according to the information received the most common type of physical restraint is the use of plastic bags and gas masks through which a brief asphyxia is achieved. The popularity of this method is caused by its simplicity and efficiency as well as safety since the victim's body leaves no marks.

Excerpt from Karaganda Region, Temirtau City Court Sentence of February 8, 2013: "K. brought plastic bags to the office to put on the head of $\mathrm{S}$. for his strangulation. T. at this moment held hands of tortured and pressed his body against the floor so that he could not resist. The illegal actions of K. and T. who obviously ignored C's cries and pleas for mercy caused him physical and mental suffering. During these tortures S. several times managed to break the plastic bag, but $\mathrm{K}$. and T. continued his stranglehold in the above manner" (Official website of the Unified Automated InformationAnalytical System of Judiciary of the Republic of Kazakhstan, 2014). 
The common method of torture used in Kazakhstan is immobilization of the victim. One way to immobilize is called "Swallow" when the victim's hands and feet are bound behind his back so that the body takes an unnatural posture that causes him severe physical and mental suffering. Typically, hands and feet are bound with elastic bandage that leaves no traces on the victim's wrists and ankles. Another method of immobilization is to make the victim face the wall with his arms behind his head and legs spread wide. Under the threat of beating the victim is not allowed to shift his feet and they gradually slide apart which causes the victim tangible pain and suffering. Handcuffs and special tricks are used widely for immobilization too.

Excerpt from No.2 Almaty district of Astana City Court Sentence No.1-453/13 of October 10, 2013: "By implementing their plans A. Sadvakassov and D. Kusainov put A. Kostenko in the office against the wall and began to beat various parts of the body thus by violence causing physical suffering. D.M. Kusainov applied special techniques in the form of a break-hand when suppressing the resistance of A.N. Kostenko" (Official website of the Unified Automated Information-Analytical System of Judiciary of the Republic of Kazakhstan, 2014).

Excerpt from Karaganda Region, Temirtau City Court Sentence of February 8, 2013: "To implement the planned K. and $T$. in their office threatened $C$. with physical violence in case the latter would not confess. When the latter refused to do so, K. and T. put handcuffs on C's hands, after having broken them behind his back, knocked him down and began to render with multiple blows to various parts of the body with their hands, feet and a special tool called "Stick Rubber - 73" (Official website of the Unified Automated Information-Analytical System of Judiciary of the Republic of Kazakhstan, 2014).

Rarely police use low voltage current. Car battery, dynamo, field detonator or phone and other similar devices can serve as current sources. Application of current small voltage cause physical and mental suffering without leaving traces of violence on the body.

Beating of victim remains one of the most common methods of torture used by the police during the investigation of crimes. However, the beating is carried out in ways that leave no trace. These are blows to the face and head of a victim with an open hand or thick books, blows to the internal organs with specially adapted objects such as plastic bottles filled with water or sand, as well as metal mug wrapped in a wet towel. One of the most popular items used by police for beating and intimidation of a victim is a special tool called "Stick Rubber-73."

Excerpt from the Pavlodar Region, Ekibastuz City Court Sentence No.1-324 of December 10, 2013: "When Sh. refused to give confessions deputy chief of the criminal police A., operative officers K., B., J., acting in a group, aware of the wrongfulness of their actions, threatened Sh. intentionally, in order to cause him physical and mental suffering and further obtain confessions of theft. I. caused a punch in the stomach of Sh. and then the neck, A. caused Sh. one hit in the face with his hand and one hit over the head with a folder with documents, K. struck Sh. one punch in the face as well as several punches to the head and neck" (Official website of the Unified Automated Information-Analytical System of Judiciary of the Republic of Kazakhstan, 2014).

Intimidation and demoralization of victims is a fundamental component of the torture. Thus, the use of painful but not dangerous enough to life and health and untraceable torture techniques accompanied by threats of applying more violent methods are able to cause a serious harm to victims. Respondents who became victims of beatings note that when a police officer punches in the wrongdoer's face, threatening at the same time that these strikes will become even more painful and dangerous to health, the victim has no reasons to doubt the seriousness of police officer's intentions. One of the police officers reported that when beating a victim one should follow the principle: "threaten harder, kick weaker".

It should be noted that different types of bullying are the most common methods of torture used in the investigation of crimes. The most common use of intimidation should recognize sexual violence and other degrading acts against the victim.

Excerpt from Kostanay Region, Uzunkol District Court Sentence No.1-7/2014 of March 17, 2014: "Police officers S. and $\mathrm{S}$. illegally using physical force in the form of bending hands behind one's back bowed suspect $B$. on a table and kept him. G. using defenseless and helpless position of B. cynically humbled honor and dignity of B. with a special tool called "Rubber Stick - 73". Causing physical and mental suffering, suppressing the will of the victim, G. began to take off B's tights, demanding confession of a crime and threatening with penetration of special tool called "Rubber Stick - 73" in the anus of the victim" (Official website of the Unified Automated Information-Analytical System of Judiciary of the Republic of Kazakhstan, 2014).

Excerpt from Karaganda Region, Temirtau City Court Sentence of February 8, 2013: "Failed getting confessions K. and $\mathrm{T}$. forcibly removed jeans, underpants and trunks from S. K. then began to threaten $\mathrm{S}$. that in case he did not confess in committing a theft, he would plunge into his anus a special tool called "Stick Rubber - 73" and report to prison about this, where the tortured had been promised to be sent to (Official website of the Unified Automated Information-Analytical 
System of Judiciary of the Republic of Kazakhstan, 2014).

Also, according to the information received, more common way used was intimidation with physical violence, causing physical suffering in various ways both to the victim and the victim's relatives by the proliferation of sensitive information such as sexual orientation or adultery.

Excerpt from East-Kazakhstan region, Ridder City Court Sentence No.1-281/12 of October 30, 2012: "At this time Deputy Head of Ridder Unit Criminal Police K. approached the victim G. and causing physical and mental suffering intentionally inflicted several punches in the face of G., while at the same time threatening him and his family with violence and sexual assault against him and demanded G. recognition of involvement in the embezzlement of Z." (Official website of the Unified Automated Information-Analytical System of Judiciary of the Republic of Kazakhstan, 2014).

Particularly noteworthy is intimidation with illegal prosecution and imprisonment. Staff engaged in crimes investigation often says "for every person there's a provision". Persons suspected of committing a crime as well as individuals who according to the police are informed about the crime are often kept in the offices or temporary detention cells much longer than envisaged by the legislation of Kazakhstan. Since people delivery to the police department is often documented improperly, a prolonged stay in the police department can be very difficult to prove.

Excerpt from No.2 Almaty district of Astana City Court Sentence No.1-453/13 of October 10, 2013: "C. causing mental suffering to the victim K. assured him that he will still go to jail for murder, and that his child will be placed in an orphanage" (Official website of the Unified Automated Information-Analytical System of Judiciary of the Republic of Kazakhstan, 2014).

To intimidate the victim police officers might also plant drugs, weapons and firearms, ammunition and other prohibited items and substances on him and then withdraw them. Such actions are usually not intended to initiate criminal prosecution against the victim. They are used solely to intimidate victims for the purpose of obtaining a confession or information.

Thus, these data confirm that the use of torture against individuals suspected of committing crimes is still systematic. Consequently, legislative and organizational measures for the prevention of torture carried out in Kazakhstan in recent years cannot be considered as effective. In our opinion, the main drawback of prevention of torture during the investigation of crimes in Kazakhstan is the lack of a comprehensive understanding of the determinants of this phenomenon.

Thus, international organizations in their earlier mentioned reports refer to the incomplete compliance disposition of national rules providing for liability for torture in Kazakhstan, the definition referred to in Article 1 of the UN Convention against Torture and Other Cruel, Inhuman or Degrading Treatment or Punishment. Moreover, in their view, the sanction of a national standard provides punishment not severe enough for subjects applying tortures.

International organizations note that torture applied during criminal investigations is often qualified for an article providing for liability for the abuse of authority by representative authorities (Article 308 of the Criminal Code of the Republic of Kazakhstan). Furthermore, this article provides a more lenient punishment than the punishment prescribed for torture (Article 141-1 of the Criminal Code of the Republic of Kazakhstan).

Mentioned drawbacks of the Kazakh legislation and legal practice definitely do not contribute to the fight against torture in the investigation of crimes and should be eliminated as soon as possible. However, there are other more serious problems.

In particular, the systematic use of torture during criminal investigations is encouraged by unjustified and logical separation of detection and investigation of crimes. In criminal procedure there are two separate bodies - the investigator who investigates crimes and operative with the status of the investigator who is responsible for the identification and detection of crime. According to reports it is operatives who systematically use torture before the official investigation is carried out by the investigator.

In practice, the procedure for detection and police investigation of most of crimes in Kazakhstan looks something like this. Operative worker under veiled pretext invites the person in respect of whom there is information about his involvement in the crime or forcibly delivers such person to the police department. Prior to official assignment to that person a suspect status operative worker asks him about the circumstances of the case. Such action is called interrogation. At this stage in accordance with Kazakhstani law a person is not able to seek help from a lawyer. If a person delivers information (police) operative does not like, the operative worker applies the methods of physical and moral pressure in order to obtain the required information. If a person reports information that satisfied the operative worker, he is then sent to the investigator, who invests such information in procedural form, and the person assigned to an official status.

This practice stipulates another problem: in most cases the investigator in Kazakhstan is not interested in solving crimes, he/she only fixes the resulting operational staff information. For this reason, the potential of investigative actions 
stipulated by the legislation of Kazakhstan is often ignored in solving crimes.

Besides in criminal proceedings in Kazakhstan such innovative methods of investigation as of polygraph and hypnosis are still not practiced, neither plea bargain institutions, nor covert investigations do exist.

Species and the order of search operations carried out by operational officers in the investigation of crimes are not clearly regulated as well. This problem is so broad and multifaceted that it definitely needs an independent study.

Another drawback to prevent the use of torture in the field of crime investigation is the absence of effective and independent verification mechanism of torture allegations and inadequate powers of the Ombudsman in Kazakhstan. In particular, reports of torture used in the investigation of crimes in Kazakhstan are either verified by their own security division of the same body to investigate the crime, or the prosecutor's office. In this and in another case validation reports of torture can hardly be considered as an independent and unbiased. It is for this reason that torture in Kazakhstan is characterized by such a high degree of latency. In many cases, victims tortured by the subjects of investigating crimes do not report about the cases of torture due to distrust in state bodies or fear of new actions of pressure from the security forces.

Special attention, in our opinion, should be given to mental causes of torture practice. "It's okay to torture a criminal, he deserves it": this psychological setting is an integral part of the subculture of subjects involved in criminal investigation. The principle that "the end justifies the means" continues to manifest itself most clearly in the criminal process in Kazakhstan. So, in order to achieve the planned performance (often unreasonably high) in solving crimes and directing criminal cases to court Kazakhstani police officers are ready to practice torture, falsification, blackmail, threats and other illegal methods of investigation.

Such settings in our opinion are not so much a consequence of flawed legislation as insufficient level of legal awareness, and sometimes legal nihilism of subjects investigating crimes. In this context, resistance to torture in Kazakhstan is not possible without increasing demands for professional adequacy of persons investigating crimes, optimization of personnel management, and improvement of school education. Measures are needed that will enable gradual shift from the corporate values of the police formed in the period of totalitarianism to universal ones.

The mental sphere should also include absolute conviction of police officers investigating crimes on the effectiveness and simplicity of torture. Thus, the operational police officers on condition of anonymity admitted that application of whether physical or mental violence to a person against whom there is evidence of his involvement in the offense and make him provide relevant evidence is much easier and faster than getting the same information in the established law order. Under constant load, the police officers' confidence in effectiveness and simplicity of torture compared to other legitimate investigative techniques is one of the key determinants of their systematic application.

However, in our opinion, the conviction of police in the simplicity and effectiveness of torture is a fallacy.

First of all, it should be noted that torture cannot guarantee the provision of reliable information. For example, Khalid Sheikh Mohammed, a man who identified himself as the organizer of the terrorist attacks of 11 September 2001 within one month was 183 times subjected to water boarding, and "confessed" to the murder of journalist Daniel Pearl which he did not commit (B. Macintyre, 2009. In the professional slang of Kazakhstani police there is the concept called "overheated". A similar expression used in those cases when under the influence of physical and mental violence people deliberately confess to a crime they did not commit, or knowingly reported false information to at least temporarily stop torture.

At the same time the recognition of a crime being interrogated under torture is legally meaningless if it is not supported by evidence obtained in the course of lawful investigations. Consequently, by getting unreliable confession investigators have subsequently to fabricate other evidence. Violations of the law by police officers in the investigation of crimes are snowballing and are often transmitted into criminal proceedings against the police officers themselves.

In addition, the opinion of J. Jeremy Wisnewski who notes that "the use of physical torture can actually increase the will of the interrogated to resist" (J.J. Wisnewski, 2010) seems to be fair enough. Indeed, criminal groups and communities in Kazakhstan are guided by unwritten moral rules which are called "rules of the underworld". Representatives of the criminal world respect "Rules of the underworld" more than the state law and religious norms. Cooperation with the police, even under torture is a willful violation of the "rules of the underworld". For this reason, representatives of criminal gangs are willing to endure any physical and mental suffering in order not to lose credibility in the criminal environment and avoid retaliation by the criminals.

\section{Conclusions}

Thus, even in terms of simplicity and efficiency the use of torture in the field of crime investigation is not appropriate. Particularly noteworthy is the lack of active civil society. In Kazakhstan there are several human rights 
organizations, which are aimed at the prevention of torture in the investigation of crimes but their endeavors, can hardly be recognized as effective. First, they do not have sufficient authority; secondly, they act separately and out of tune; and thirdly, they are not popular among the population. The largest part of people of Kazakhstan prefers not to intervene in the conflict between government institutions and individuals, including allegations of torture, unless it affects them personally or their families. This attitude often complicates the process of bringing the police torturers to justice.

We hope that the views expressed in the current paper will be of interest and of use to all individuals and organizations interested in the complete and unconditional eradication of torture in investigating crimes in Kazakhstan and other Central Asian states.

\section{References}

Annual Report. (2011). The state of the world's human rights. Amnesty International. [Online] Available: http://www.amnesty.org/en/ annual-report/2011 (June, 2014).

Annual Report. (2012). The state of the world's human rights. Amnesty International. [Online] Available: http://www.amnesty.org/en/ annual-report/2012 (June, 2014).

Annual Report. (2013). The state of the world's human rights. Amnesty International. [Online] Available: http://www.amnesty.org len/annual-report/2013 (June, 2014).

Eaias.supcourt.kz. (2014). Official website of the Unified Automated Information-Analytical System of Judiciary of the Republic of Kazakhstan. [Online] Available: http//www.eaias.supcourt.kz/EGOV/QB.NSF/QForm?OpenForm\&Lang=ru (May, 2014).

Görling, R. (2012). Torture and Society. Speaking about Torture. Fordham University Press.

Macintyre, B. (2009, April 23). '24' is fictional. So is the idea that torture works. Retrieved April 28, 2011. [Online] Available: http://www.timesonline.co.uk/tol/comment/columnists/ben_macintyre/article6150151.ece (May, 2014).

Osce.org (2012). Fourth Expert Forum on Criminal Justice for Central Asia. 29-31 October 2012. Final Report. [Online] Available: www.osce.org/odihr/99506 (April, 2014).

Peters, E. (1996). Torture. Expanded edition. University of Pennsylvania Press.

Report. (2011). A World of Torture. Action by Christians for the abolition of torture: Kazakhstan. [Online] Available: http://unmondetortionnaire.com/Kazhakhstan\#lire (June, 2014).

Statistical information on registered crimes under Art. 141-1 of the Penal code in the Republic of Kazakhstan for the period from 2009 to 2013. (2014). [Online] Available: http://service.pravstat.kz/portal/page/portal/POPageGroup/Services/Pravstat (July, 2014).

Wisnewski, J.J. (2010). Understanding torture. Edinburgh University Press.

World Report. (2014). Events of 2013. [Online] Available: www.hrw.org/world-report/2014 (May, 2014).

Write for rights. (2013). Final report. [Online] Available: http://amnesty.org/en/library/asset/ACT30/006/2014/en/5c339817-b95d-44e38e1d-14000964ce30/act300062014en.pdf (June, 2014). 